O. O. Knyzhenko ${ }^{1}$, Dr. Sc. (Jurid.), Prof., orcid.org/0000-0001-9252-7464, S. O. Knyzhenko ${ }^{2}$, Cand. Sc. (Jurid.), Assoc. Prof., orcid.org/0000-0002-1944-4256,

K. V. Yurtayeva ${ }^{2}$, Cand. Sc. (Jurid.), Assoc. Prof., orcid.org/0000-0002-6096-2020

\title{
ILLEGAL MINING OF MINERAL RESOURCES OF THE NATIONAL IMPORTANCE: ISSUES OF SUBSOIL PROTECTION WITH CRIMINAL-LEGAL REMEDIES
}

Purpose. Complex, science-based research on acts described in Part 2 of Article 240 of the Criminal Code of Ukraine and practice of their investigation as an indispensable component of subsoil protection. Issues of classifying illegal mining of national importance and the investigation of these crimes are considered.

Methodology. Method of system analysis of acts related to illegal mining is used. Due to the system-structural and logical methods, an investigator's activities when investigating these crimes are studied and analyzed.

Findings. The results of the study are determined by the fact that the need is proved for recognition of illegal mining of mineral resources as a completed offence from the moment of committing an act aimed at seizing mineral resources by any means. Expediency was substantiated to consider actions as minor ones in cases when illegal mining of mineral resources by its quantity, scale, character and other features neither did nor could cause considerable harm to the environment. The article defines subjects of collaboration during investigating illegal mining of mineral resources. The need is substantiated for the investigator to use modern unmanned compact aircraft systems when inspecting the scene during the investigation of these crimes. These devices will help in fixing the course and results of the inspection, as well as in prosecuting criminals, the delivery of small loads to the scene when necessary.

Originality. The authors article have proved the necessity of considering illegal mining of mineral resources to be a completed offence from the moment of committing an act aimed at their extraction by any means. A circle of subjects and tasks of collaboration during investigation of illegal mining is defined. Feasibility of using copters when inspecting a crime scene is substantiated.

Practical value. The work will help law-enforcement authorities to classify illegal mining activities properly; it guides an investigator regarding the circle of subjects and tasks of collaboration; it will give recommendations on selecting forensic tools when inspecting a crime scene in the commission of these crimes.

Keywords: subsoil protection, mineral resources, illegal mining, unmanned aircraft, subjects of collaboration

Introduction. Subsoil is one of the essential resources of the economy of any country, including Ukraine. Mining of mineral resources is one of the forms of subsoil exploitation which is the exclusive preserve of the Ukrainian people and that may be granted only for exploitation. Criminal transgressions in the sphere of mining of mineral resources of the national importance cause harm not only to the economy of Ukraine, but also to the environment. Unfortunately, over recent years the rate of illegal mining of mineral resources in Ukraine has escalated significantly. Natural gas, coal, amber, sand, clay, building stone, and peat become subjects of illegal mining in Ukraine most frequently. This situation calls for enhancement of criminal-legal remedies of counteracting such offences, without which no efficient subsoil protection is possible.

In this connection particular significance should be given to the issues related to defining the forms of criminal conduct, described in art. 240, part 2, of the Criminal Code of Ukraine, and peculiarities of investigating this offence as an essential part of subsoil protection.

Literature review. In the scientific literature considerable attention is devoted to characteristics of objective and subjective features, described in Article 240 of the Criminal Code of Ukraine. In particular, scientists thoroughly examined features of the subject of the offence, the forms of criminal conduct, issues of delimitation of criminal offence from administrative transgression and others. Scientists also proposed ways of enhancement of this norm.

A number of scientific publications are devoted to general issues of methodology of investigating crimes against the environment. Specific issues pertaining to investigating illegal mining of mineral resources were examined by D. O. Olekseieva-Protsiuk, O. M. Biriukov, O. M. Bryskovskyi, O. Y. Tatarov,

(C) Knyzhenko O. O., Knyzhenko S. O., Yurtayeva K. V., 2020 and others. At the same time a number of issues remain highly debatable, mistakes in criminal-legal qualification of such offences and examples of their inefficient investigation are also common.

Unsolved aspects of the problem. Studying judicial practice indicates that not all issues have been well comprehended. One of them is defining the moment of completion of illegal mining of mineral resources. Therefore, examining this issue in cases of illegal amber exploitation, which is one of the most common offences of this category, is extremely urgent.

Taking into consideration contemporary tasks of forensic science and forensic methodology, specific elements of methods engaged in investigating illegal mining of mineral resources also require advanced research.

Purpose of the article is to provide a complex, sciencebased research on illegal mining of mineral resources of the national importance and practice of its investigation as an essential component of subsoil protection.

The article outlines issues of criminal legal qualification of illegal mining of mineral resources of the national importance (art. 240, part 2, of the Criminal Code of Ukraine), namely ascertains the moment of completion of criminal conduct. The article also examines issues of investigation of such offences.

In order to achieve the defined objective the following tasks have to be resolved:

- ascertaining the forms of criminal conduct, described in art. 240, part 2, of the Criminal Code of Ukraine;

- indicating drawbacks of legislative technique in constructing art. 240, part 2, of the Criminal Code of Ukraine;

- analyzing practice of investigating illegal mining of mineral resources of the national importance;

- defining a range of subjects of collaboration in investigating illegal mining of mineral resources of the national importance; 
- defining tactical peculiarities of crime scene examination.

Methods. The defined objective has been achieved engaging systematic analysis of conduct constituting illegal mining of mineral resources. By the use of system-structural and logical methods the article analyzes investigative practice during investigation of the analyzed criminal offences.

Results. Examination of judicial practice in the offences under art. 240 of the Criminal Code of Ukraine (the Form 6 "Report on the number of persons convicted, acquitted, criminal cases against whom were closed, recognized insane, against whom compulsory medical measures or criminal penalties were applied") indicates that during the last three years persons were convicted only for offences under art. 240, parts 2 and 3, of the Criminal Code of Ukraine [1]. Such statistics indicates not so much the lack of the facts of commission of such offences as rather drawbacks of the legislative technique, which prevents or introduces considerable complexity into application of this norm, and, as a result, significantly reduces the efficiency of criminal-legal remedies of subsoil protection.

Debate is aroused by the interpretation of the phrase "mining of mineral resources" used in art. 240 of the Criminal Code of Ukraine, because mining can be interpreted either as a process or as a result of such process. Precisely, the meaning of this phrase determines definition of the moment of completion of the studied offence. If mining is interpreted as a process, the offence will be considered completed, when such process has begun; if mining is interpreted as a result, the offence will be considered completed from the moment of extracting certain quantity of mineral resources.

Two options of the interpretation sited above are observed in the examined judicial practice. For instance, conduct of a person who has started mining mineral resources, but could not complete extraction owing to the lack of time, is qualified as an attempted offence. It should be also mentioned, that in some cases courts qualified such conduct as a consummated criminal attempt [2], in others - as an unconsummated criminal attempt [3].

However, despite of the sited court judgments, judicial practice also contains contradictory decisions, where conduct constituting mining of mineral resources without their actual separation from geological formation, was qualified as completed offence under art. 240, part 2, of the Criminal Code of Ukraine [4].

Judicial practice also contains such judgments which do not specify the character of a culprit's conduct. For instance, Volodymyretskyi regional court of Rivne region qualified conduct of a person aimed at realization of an attempt to mine amber with the use of motorized pump of craft production equipped with an internal combustion engine and designed for pressurized water supply through hydroerosion as an unconsummated criminal attempt. The judgment was passed upon the pleading guilty agreement. From its content it is impossible to comprehend either the person has started mining or only transported equipment to the crime scene [5].

Bearing in mind that the norm of art. 240, parts 2 , of the Criminal Code of Ukraine is blanket, it is necessary to address other statutes regulating mining of mineral resource to clarify its meaning.

According to art. 1, part 1, paragraph 5, of the of the Law of Ukraine "On state regulation of extraction, production and usage of precious metals and gemstone and control over operations with them" of 18.11.1997 No. 637/97-BP, extraction of precious metals (they belong to mineral resources) should be understood as extraction of precious metals from subsoil and from the waste of mining and metallurgical production (tailings piles, tailings, slags, slimes, cinder) by any possible means. This leads to the conclusion that illegal mining of mineral resources will be completed from the moment of completion of conduct aimed at extraction of the deposits of mineral resources by any possible means (pumping, building mines, quarries, blow-outs and abstraction from wells, volatilisation or related techniques).

Examination of the norm leads to the conclusion that quantity of extracted mineral resources falls outside the features of objective side of corpus delicti of the studied offence. Accordingly, for persecuting a person under art. 240, part 2, of the Criminal Code of Ukraine, it is essential to define that the process of mining has been started.

This conclusion is supported by systematic interpretation of the Criminal Code of Ukraine. For instance, in art. 248, part 1, of the Criminal Code of Ukraine likewise in art. 240, part 2, of the Criminal Code of Ukraine, the legislator has outlined forms of criminal conduct that differ by the moment of their completion. In order to emphasize that violation of the rules related to hunting is completed not from the moment of beginning of hunting, but rather is associated with its "results", the legislator in art. 248, part 1, of the Criminal Code of Ukraine provides socially dangerous consequence in the form of causing substantial damage. In cases when hunting is conducted in national parks or any territories and sites of natural conservation, it is not necessary to establish that substantial damage has been caused.

Due to such legal construction, the legislature emphasizes considerable social danger of hunting in national parks or any territories and sites of natural conservation. Therefore, it is not essential that the prey was shot or caught; for initiating criminal proceedings it is sufficient to identify actions aimed at tracking or chasing animals with the intent of their extraction.

This conclusion is based on legislative definition of hunting in art. 1 of the Law of Ukraine "On hunting industry and hunting". For instance, hunting is interpreted as tracking, chasing hunted species, which live in the wild or are detained in half-wild conditions, with the aim of hunting as well as hunting itself (shooting, culling). It is noteworthy that this opinion is stipulated in all textbooks on Criminal Law and commentaries on the Criminal Code of Ukraine.

We consider that the moment of completion of the offence under art. 240, part 2, of the Criminal Code of Ukraine should be defined in a similar way. In scientific literature, it has been consistently emphasized that this norm, in fact, contains two different corpora delicti (the first - violation of stipulated rules of subsoil exploitation, which can cause danger to human health and the environment; the second - illegal mining of mineral resources of the national importance), and, what is more, it is proposed to provide them in different articles of the Criminal Code of Ukraine. Emphasizing one more time, that such legislating construction first and foremost demonstrates discrepancy in the objective side of the analyzed offences, which among other features is expressed by the moment of their completion. Consequently, the first analyzed form of criminal conduct is completed from the moment of causing danger to human health and the environment. The second form of criminal conduct is completed from the beginning of mining mineral resources, which should be viewed as a process and not as a result. Therefore, we consider that the last form can be better described by the notion "extraction".

It should be also emphasized that this offence encroaches upon the environment rather than property right. This fact also supports the idea that the moment of crime completion does not require completion of illegal seizure of mined mineral resources, because damage to the environment is caused at the time of their extraction.

In this regard, it is essential to resolve the issue of a minor action. We consider that in cases, when illegal mining of mineral resources by its quantity, scale, character and other features neither did nor could cause considerable harm to the environment, such acts should be considered a minor action under art. 11, part 2, of the Criminal Code of Ukraine. Accordingly, a conduct of a person, who using a spade has loaded sand-gravel compound (gravel) and transported it by truck to his household in order to place it near their house [6], in our 
opinion should be considered a minor action. Nevertheless, the court justified otherwise and prosecuted this person for a criminal offence. The fact that the harm to the environment has not been caused is substantiated not only by the quantity of extracted mineral resources, but primarily by the engaged means that were not endangering the environment. It should be mentioned that this issue is debatable, since damage to the environment can be caused as a result of separate actions, which cumulatively cause criminal consequence, when an isolated action is not able to cause such harm. Despite high incidence of such instances in our country, a person must not be prosecuted for the harm caused by the third parties. This conclusion is based on the conventional causation theory in Criminal law. Consequences must be in a necessary casual connection with committed action. A person can be prosecuted only for those actions, which have "generated" the emerged consequences. If the consequence is triggered by several factors, the state should develop a complex of criminological measures for their prevention. The history of criminal-legal doctrine substantiates that the effort to resolve environmental protection issues solely by criminal-legal remedies is inefficient. Moreover, it should be noted, that prevalence of certain practices is one of the bases of their decriminalization, since prosecution becomes selective. It provides additional arguments for the need of stipulating not only criminal-legal, but also other kinds of remedies for enhancing prevention of illegal mining of mineral resources.

Considering peculiarities of investigating such crimes, it should be noted, that most frequently law enforcement bodies acquire evidence of illegal mining of mineral resources from environmental authorities and individual citizens. The investigator also collaborates with operational units, enterprises, institutions, civil society. For example, O. V. Oderii points out the need of collaboration between the investigator and civil society in conducting investigation of environmental offences [7].

Given that most law violations in the sphere of subsoil protection are detected by environmental authorities, issues of elaborating efficient methods of collaboration between the investigator and officials of state environmental authorities require further examination, as an essential condition of prompt and full investigation of illegal mining of mineral resources.

Conducted analysis of investigative practices of such offences allows determining the following subjects of collaboration from state environmental authorities:

- Public Environmental Inspection of the Ministry of Ecology and Natural Resources of Ukraine;

- Public Agency of Forest Resources of Ukraine;

- Public Service of Geology and Subsoil of Ukraine;

- Public Agency of Land Resources of Ukraine;

- executive authorities and local self-government bodies.

It is noteworthy, that efficiency of coherence between the investigator and defined subjects of collaboration mostly depends on its duration, which may have ad hoc or short-term character or be continuously conducted during a considerable period of time.

Conducted analysis of investigative practices of illegal mining of mineral resources demonstrates that collaboration between the investigator and environmental authorities most frequently have the following forms: 1) receiving information on a crime; 2) engaging experts to conducting investigative (detective, search) actions; 3 ) providing counselling; 4) providing materials of inspections.

It should be emphasized, that the Public Environmental Inspection monitors compliance with the requirements of legislature in the sphere of environmental protection, conducts management, reproduction and protection of natural resources and other tasks defined by the law. That is why the investigator most frequently engages officers of this governmental authority to crime scene examination, providing counselling on the issues of mineral resources exploitation and obtaining materials of inspections.
Due to the fact that illegal mining of mineral resources frequently takes place at the lands of the state forestry fund and harm is caused to the forestry, the investigator has to collaborate with the officials of local departments of the Public Agency of Forest Resources of Ukraine. According to the legislature, the Public Agency of Forest Resources of Ukraine holds an obligation of maintaining the public forest cadastre and forest inventory; conducting forest monitoring; conducting classification of forests by categories; approving the age of maturity of standing timber; organizing authorization of special permits for forest resources exploitation in accordance with the procedure established by law.

Investigating illegal mining of mineral resources, the investigator also collaborates with the Public Service of Geology and Subsoil of Ukraine, which maintains:

- state balance of mineral reserves;

- national cadastre of mineral deposits and occerrences;

- public inventory of underground waters and water cadastre;

- public record and inventory of works and research related to geological subsoil exploration.

Law enforcement agencies receive information on the deposits of mineral resources in a certain area from the Public Service of Geology and Subsoil of Ukraine that allows detecting the facts of illegal mining of mineral resources, and also conducting preventive measures.

According to the legislature, the Public Agency of Land Resources of Ukraine conducts monitoring and protection of lands; maintains public registration of plots and restrictions of their utilization; maintains land records and issues statements on plot from the national land cadastre; maintains and administrates the national land cadastre and receives information on land use and so on. The investigator contacts this authority to define the type of land, where illegal mining of mineral resources took place, and also its ownership.

The investigator receives information on special permits on subsoil exploitation and mining leases from executive authorities and local self-government bodies. Equally, the investigator must always inform these bodies about disclosed facts of illegal mining of mineral resources in order to restore secure state of the plot, where illegal exploitation took place. It is worth noting, that the lands upon illegal mining of mineral resources remain in the unusable condition due to removing top layer of fertile land, remaining continuously under colliery waste or sludge stores etc. Specialists emphasize that after mining of mineral resources, including illegal mining, one can observe lawn destruction, ruining of humus horizons, accompanied by changes in the soil structure, creation of new microlandscapes, formation of cracks, sinkholes, and even changing area terrain and land degradation [8].

Moreover, illegal mining of mineral resources creates a real risk for life and health not only of people, engaged in illegal mining, but also of local residents (due to the possible collapses of ground, spontaneous combustion of mining rock, flooding of mine galleries, and others). In our opinion, the investigator must inform local self-government bodies in order to take measures for lands remediation, including restoration of the terrain (filling in ravines and quarries, eliminating colliery wastes).

Investigating the analyzed offences, the investigator collaborates with operational units, including operational units of the National police. Such collaboration is conducted in procedural and non-procedural forms. The following forms of collaboration are most frequently used: participation of operational officer in the investigative (detective, search) actions, execution of specific assignments, holding joint meetings and information-sharing. In cases when illegal mining of mineral resources is committed by an organized criminal group, an investigative operational group should be created for conducting pre-trial investigation. Typical tasks of such collaboration are the following: detecting and apprehending all participants of 
the criminal groups, detecting ways of sale of illegally mined mineral resources, uncovering all episodes of criminal activity.

Specific tactical methods for examination of the incident site are the next peculiarity of investigating the analyzed offences. Results of our research lead to a conclusion that site of the incident is most frequently presented by open areas. Taking into consideration such characteristic of site of the incident, the investigator should use such modern scientific and technological means as copters. These unmanned aerial vehicles are able to fulfil several tasks:

- carrying out exploration of plots for identifying other sites of illegal mining of mineral resources;

- defining limits of crime scene examination;

- conducting photo and visual recording of investigative (detective, search) action;

- hot pursuit of perpetrators;

- transporting small-size cargoes to site of the incident.

The following characteristics of copters are essential for crime scene examination: high level of manoeuvring; capacity to stay fixable in a specified position and stand still above the recorded object; resistance to atmospheric influences; fixation of radar and capacity to return to the reference point; transmitting parameters in real-time; capacity to take high-quality images; possibility of camera regulation; direct transmitting and recording of data to a remote equipment [9].

Copters also provide possibility to record entire surrounding situation in cases of multiple trace patterns [10].

One more peculiarity of investigating illegal mining of mineral resources is that the investigator quite often discovers equipment used for mining mineral resources and their transportation (pumps, excavators, trucks, and so on). This kind of equipment/vehicles is quite massive, that is why the investigator must in advance decide where and how to store it. Before seizure, it is important to conduct thorough examination of the machinery observing all tactical rules, including detecting and recording the fingerprints.

Moreover, at the time of crime scene examination the investigator also discovers illegally mined mineral resources and therefore has to make a decision about their seizure, storage and direct the patterns to forensics. To accomplish this task, the investigator engages both trucks and technical assistance for loading and transporting illegally mined mineral resources to the place of their storage.

Conclusion. With a view to enhance subsoil protection, the article substantiates the thesis that illegal mining of mineral resources should be considered a completed offence from the moment of committing an act aimed at extracting mineral resources by any means.

In cases when illegal mining of mineral resources by its quantity, scale, character and other features neither did nor could cause considerable harm to the environment, such acts should be considered a minor action.

Investigating illegal mining of mineral resources of the national importance require close collaboration between the investigator and the following subjects: the Public Environmental Inspection of the Ministry of Ecology and Natural Resources of Ukraine; the Public Agency of Forest Resources of Ukraine; the Public Service of Geology and Subsoil of Ukraine; the Public Agency of Land Resources of Ukraine; executive authorities and local self-government bodies; operational units; enterprises and institution; civil society.

Spacious extend and specificity of illegal mining of mineral resources require the use of contemporary compact unmanned aerial vehicles for facilitating not only recording of the process and results of crime scene examination, but also pursuing offenders, transporting small-size cargoes to site of the incident, when required.

At the time of crime scene examination the investigator also makes decisions on a number of issues connected with seizure and storage of crime instruments as well as the object of criminal infringement.
References.

1. Report on persons prosecuted and types of criminal penalties (2017). Retrieved from https://court.gov.ua/inshe/sudova statystyka/.

2. The verdict of Olevskyi District Court of Zhytomyr region of December 27, 2018 in case No. 27/12/2018-k (2018). Retrieved from http://www.reyestr.court.gov.ua/Review/78900002.

3. The verdict of Sarnenskyi District Court of Rivne region of 11/02/2019 in case No. 571/1726/18 (2019). Retrieved from http://www.reyestr.court.gov.ua/Review/79734553.

4. The verdict of Dubrovytskyi District Court of Rivne region of 18/12/2018 in case No 560/1654/18 (2018). Retrieved from http://www.reyestr.court.gov.ua/Review/78623541.

5. The verdict of Volodymyretskyi District Court of Rivne region of 26/11/2018 in case No 556/1834/18 (2018). Retrieved from http://www.reyestr.court.gov.ua/Review/78097403.

6. The verdict of Nadvirnianskyi District Court of Ivano-Frankivsk region of 15/03/2019 in case No 348/1416/18 (2019). Retrieved from http://www.reyestr.court.gov.ua/Review/80475387.

7. Oderii, O. V. (2018). Pre-trial investigation of environmental crimes (role of public relations). In Aktualni pytannia zabezpechennia publichnoi bezpeky, (pp. 202-204). Mariupol, Ukraine.

8. Budziak, O. S. (2014). Degradation and measures aimed at land revitalization of Ukraine. Zemleustrii, kadastr i monitorynh zemel, (1-2), 57-64.

9. Baryshnikov, K. V., \& Cherviakov, M. E. (2012). On the issue of the use of unmanned aerial vehicles during the inspection of the scene. Epokha nauki, (14), 19-21. https://doi. org/10.1555/2409-3203-2018-0-14-19-22.

10. Shvets, S. V., \& Shumaev, D. G. (2018). State-of-the-art possibilities of photofixing the scene of an accident upon the explosion. Retrieved from http://dom-hors.ru/rus/files/arhiv zhurnala/pep/2018/11/law/shvets-shumaev.pdf.

\section{Незаконне видобування корисних копалин загальнодержавного значення: питання охорони надр кримінально-правовими засобами}

\section{О. О. Книженко ${ }^{1}$, С. О. Книженко ${ }^{2}$, К. В. Юртаєва ${ }^{2}$}

1 - Національна академія прокуратури України, м. Київ, Україна, e-mail: 2015knio@gmail.com

2 - Харківський національний університет внутрішніх справ, м. Харків, Україна, e-mail: mega_kni-svetlana@ukr. net; yurtayeva@gmail.com

Мета. Комплексне, науково обгрунтоване дослідження діянь, описаних у ч. 2 ст. 240 КК України та практики їх розслідування як невід'ємної складової охорони надр. Розглянуті проблеми кваліфікації незаконного видобування корисних копалин загальнодержавного значення й питання розслідування цих злочинів.

Методика. Використані методи системного аналізу дій, що полягають у незаконному видобуванні корисних копалин. Завдяки системно-структурному й логічному методам досліджена та проаналізована діяльність слідчого при розслідуванні вказаних злочинів.

Результати. Результати дослідження визначаються тим, що доведена необхідність визнання незаконного видобування корисних копалин закінченим злочином з моменту вчинення дій, спрямованих на їх вилучення будь-яким способом. Обгрунтована доцільність визнання малозначним діяння, що в разі незаконного видобування корисних копалин за обсягом, масштабом, способом й іншими обставинами, що не заподіяли й не могли заподіяти істотної шкоди довкіллю. Окреслене коло суб'єктів і завдання взаємодії при розслідуванні незаконного видобування корисних копалин. Вмотивована не- 
обхідність використання слідчим сучасних безпілотних компактних літальних апаратів під час огляду місця події при розслідуванні вказаних злочинів. Такі засоби допоможуть у фіксації ходу і результатів огляду, а також у переслідуванні злочинців, доставці малогабаритних вантажів на місце події за необхідністю.

Наукова новизна. Полягає в тому, що авторами доведена необхідність визнання незаконного видобування корисних копалин закінченим злочином 3 моменту вчинення дій, спрямованих на їх вилучення будь-яким способом. Визначене коло суб'єктів і завдання взаємодії при розслідуванні незаконного видобутку корисних копалин. Обгрунтована необхідність використання під час огляду місця події безпілотних літальних апаратів.

Практична значимість. Визначається тим, що допоможе правоохоронним органам правильно кваліфікувати дії щодо незаконного видобутку корисних копалин; зорієнтує слідчого стосовно кола суб'єктів і завдань взаємодії; надасть рекомендації щодо вибору криміналістичних засобів під час огляду місця події при вчиненні цих злочинів.

Ключові слова: охорона надр, корисні копалини, незаконне видобування, безпілотні апарати, суб'єкти взаємодіі

\section{Незаконная добыча полезных ископаемых общегосударственного значения: вопросы охраны недр уголовно-правовыми средствами}

\section{О. А. Книженко ${ }^{1}$, С. А. Книженко ${ }^{2}$, К. В. Юртаева ${ }^{2}$}

1 - Национальная академия прокуратуры Украины, г. Киев, Украина, e-mail: 2015knio@gmail.com

2 - Харьковский национальный университет внутренних дел, г. Харьков, Украина, e-mail: mega_kni-svetlana@ukr. net; yurtayeva@gmail.com

Цель. Комплексное, научно обоснованное исследование деяний, описанных в ч. 2 ст. 240 УК Украины, а также практики их расследования как неотъемлемой составляющей охраны недр. Рассмотрены проблемы квалификации незаконной добычи полезных ископаемых общегосударственного значения и вопросы расследования этих преступлений.

Методика. Использованы методы системного анализа деяний, связанных с незаконной добычей полезных ископаемых. Благодаря системно-структурному и логическому методам исследована и проанализирована деятельность следователя при расследовании указанных преступлений.

Результаты. Результаты исследования определяются тем, что доказана необходимость признания незаконной добычи полезных ископаемых оконченным преступлением с момента совершения действий, направленных на их изъятие любым способом. Обоснована целесообразность признания малозначительными действий, которые в результате незаконной добычи полезных ископаемых по объему, масштабу, способом и другим обстоятельствам не причинили и не могли причинить существенный вред окружающей среде. Очерчен круг субъектов, а также задачи взаимодействия при расследовании незаконной добычи полезных ископаемых. Мотивирована необходимость использования следователем современных беспилотных компактных летательных аппаратов во время осмотра места происшествия при расследовании указанных преступлений. Эти средства помогут в фиксации хода и результатов осмотра, а также в преследовании преступников, доставке малогабаритных грузов на место происшествия по мере необходимости.

Научная новизна. Заключается в том, что авторами доказана необходимость признания незаконной добычи полезных ископаемых оконченным преступлением с момента совершения действий, направленных на их изъятие любым способом. Определен круг субъектов и задачи взаимодействия при расследовании незаконной добычи полезных ископаемых. Обоснована необходимость использования при осмотре места происшествия беспилотных летательных аппаратов.

Практическая значимость. Определяется тем, что поможет правоохранительным органам правильно квалифицировать действия по незаконной добыче полезных ископаемых; ориентирует следователя относительно круга субъектов и задач взаимодействия; даст рекомендации по выбору криминалистических средств при осмотре места происшествия при совершении этих преступлений.

Ключевые слова: охрана недр, полезные ископаемые, незаконная добыча, беспилотные аппараты, субъекты взаимодействия

Recommended for publication by P. Serdiuk, Doctor of Juridical Sciences. The manuscript was submitted 12.05.19. 